Proc. Estonian Acad. Sci. Geol., 2002, 51, 2, 67-87

\title{
Upper Llandovery to middle Wenlock (Silurian) lithostratigraphy and chitinozoan biostratigraphy in southwestern Estonia and northernmost Latvia
}

\author{
Heldur Nestor and Viiu Nestor \\ Institute of Geology, Tallinn Technical University, Estonia pst. 7, 10143 Tallinn, Estonia; \\ hnestor@gi.ee, vnestor@gi.ee \\ Received 26 June 2001, in revised form 6 September 2001
}

\begin{abstract}
The lithostratigraphy and chitinozoan biostratigraphy of the Adavere, Jaani, and Jaagarahu regional stages (upper Llandovery to middle Wenlock) in the Ikla (Estonia) and Staicele (Latvia) drill cores were studied. Most of the upper Aeronian to lower Homerian local chitinozoan biozones are represented in these cores, except Interzone III, Angochitina longicollis, Conochitina proboscifera, and Margachitina margaritana biozones, partly corresponding to barren red beds of the Velise Formation, partly to a stratigraphical gap at the Llandovery-Wenlock transition. The presence of Stricklandia laevis shows that the Rumba Formation of the Adavere Stage belongs to the Telychian. The succeeding, Velise Formation has a reduced thickness and is represented only by its lower portion. Three stratigraphical gaps were established at the boundaries of the regional stages. The hiatuses at the junctions of the Raikküla-Adavere and Adavere-Jaani stages have a considerable areal extent and stratigraphical range. Probably, they reflect global glacio-eustatic falls of sea level at the end of the Aeronian and Telychian corresponding to the glaciations in South America. A gap at the base of the Jaagarahu Stage was recognized only in the Ikla core and has local significance.
\end{abstract}

Key words: lithostratigraphy, chitinozoan biostratigraphy, stratigraphical gaps, Llandovery, Wenlock, Estonia.

\section{INTRODUCTION}

The subsurface sequence of Llandovery carbonate and calcareous-argillaceous rocks is thickest and most complete in southwestern mainland Estonia and northernmost Latvia. The Llandovery sequence reaches $231 \mathrm{~m}$ thick in the Ikla drill core (Estonia) and $222 \mathrm{~m}$ in the Staicele drill core (Latvia) (Fig. 1), more than twice the thickness of the series in outcrops in central and western Estonia. The Ikla and Staicele sections exhibit the transition from shelly to graptolite biofacies and have received attention as the type sections of several lithostrati- 


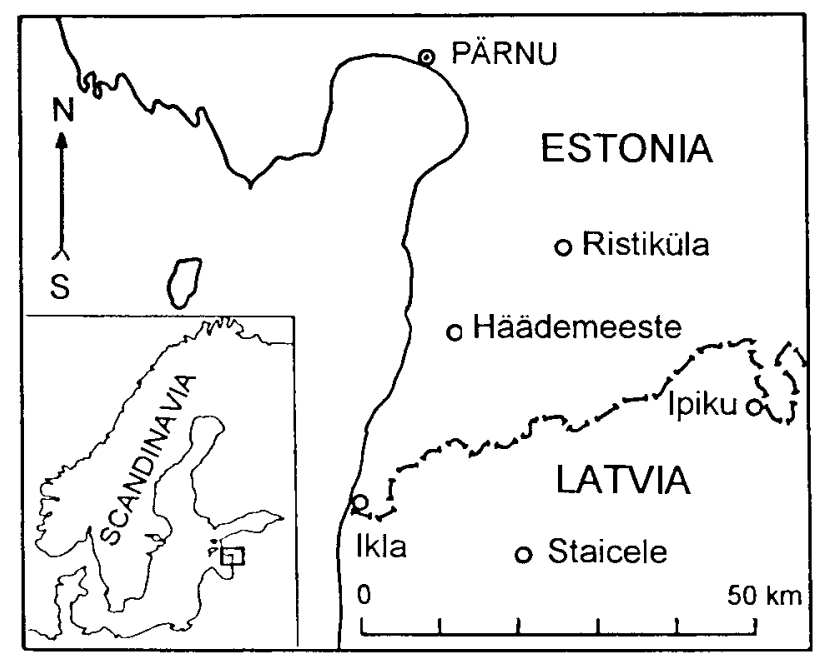

Fig. 1. Location of drill holes in southwestern mainland Estonia and northernmost Latvia figured in Figs. $2-4$.

graphical units (Saarde Formation, Ikla, Lemme, and Staicele members). However, up to now only the more calcareous rocks of the Juuru, Raikküla, and the lower part of the Adavere regional stages, corresponding to the lower and middle Llandovery, have been sufficiently well studied. The litho- and biostratigraphy of the Ikla and Staicele cores have been treated by Kaljo \& Vingisaar (1969), Ulst (1973), and Gailite et al. (1987). The data from the Ikla core have been used for elaboration of the regional chitinozoan biozonation (V. Nestor 1976, 1994) and as a constituent part of several geological transects (e.g. H. Nestor \& Einasto 1982; Einasto 1984; H. Nestor 1997).

Only scanty published data are available on the upper part of the Ikla and Staicele cores which contain argillaceous rocks of the upper Llandovery (Velise Formation) and the lower-middle Wenlock (Jaani and Jaagarahu regional stages). Ulst (1973) considered that the whole complex of the uppermost marlstones in the Staicele core and a great part of the Ikla core belong to the Velise Formation of the Adavere Stage. Aaloe (1970) supposed that the Ikla core ends at the top of the Jaani Stage. Recent study of chitinozoans from the upper portions of the Ikla and Staicele cores proved that both reach much higher in the stratigraphical succession than previously supposed.

The present paper is based on the macrolithological investigation and sampling of the Staicele core at the Katlakalns depository of the Latvian Geological Survey near Riga and the Ikla core at the Keila depository of the Estonian Geological Survey near Tallinn. Also, unpublished descriptions of the Ikla core by Peeter Vingisaar and Rein Einasto were used.

The lithostratigraphy and chitinozoan biostratigraphy of the Adavere, Jaani, and Jaagarahu regional stages are considered. The Adavere Stage corresponds 
roughly to the upper Llandovery (Telychian), the others to the lower and middle Wenlock (Sheinwoodian to lower Homerian). The lithostratigraphical units used are the same as those in the recent Silurian stratigraphical scheme of Estonia (H. Nestor 1997).

\section{LITHOSTRATIGRAPHY}

\section{Adavere Stage}

The Adavere Stage is represented in the Staicele and Ikla cores by the Rumba (below) and Velise (above) formations (Figs. 2 and 3). In western Estonia the Rumba Formation typically consists of variably argillaceous, nodular to wavybedded biomicritic limestones (packstone and wackestone) with accumulations of the brachiopod Pentamerus oblongus at certain levels. In general, the formation is characterized by distinct low-rank cyclicity (Einasto et al. 1972). In the Ikla and Staicele cores the cyclicity is less conspicuous and pentamerids are rare, representing a mixed Pentamerus-Stricklandia community. From the Rumba Formation of the Ikla core, Rubel (1977) has identified Stricklandia lens ultima (= Stricklandia laevis (Sowerby)), which is a guide fossil of the Telychian.

In the interval of 295.0-329.5 m of the Staicele core the Rumba-type nodular wackestones are almost twice as thick as the Rumba Formation in the Ikla core (304.8-322.3 m). In previous publications (Ulst 1973; Gailite et al. 1987) the whole or a great part of these strata is included in the Staicele Member of the Saarde Formation. However, from the lithostratigraphical point of view it seems plausible to include the entire complex of nodular wackestones in the Rumba Formation, assuming that the formation of the Rumba-type rock might have commenced somewhat earlier in the vicinity of Staicele.

The Velise Formation has a reduced thickness in both cores and bears some specific lithological features. In the Staicele core the interval of 292.5-295.0 m is represented by interbedded reddish-brown to varicoloured, bioturbated marlstones and argillaceous limestones containing an interlayer with ferruginous (iron) oolites at a depth of 293.6-293.7 m. The topmost $15 \mathrm{~cm}$ of the interval contains stromatolites and several limonitic encrustations, probably representing discontinuity surfaces.

In the Ikla core the Velise Formation ranges through the interval of 296.0 $304.8 \mathrm{~m}$. It is represented by reddish-brown to grey, argillaceous marlstone with limestone nodules. Some bentonite interlayers, discontinuity surfaces, and scattered oolites are observed in the middle of the interval. At the base of the formation there occurs a series of at least eight limonitic discontinuity surfaces. Several discontinuity surfaces are recorded also higher up in the section, one lying at the top of the formation. Rounded pebbles of pyritized argillaceous limestone occur above the discontinuity surfaces at depths of 297.1 and $298.2 \mathrm{~m}$. The Velise Formation is almost barren of micro- and macrofossils. The reduced thickness of rocks, restricted number of ash layers, presence of oolites, discontinuity surfaces 


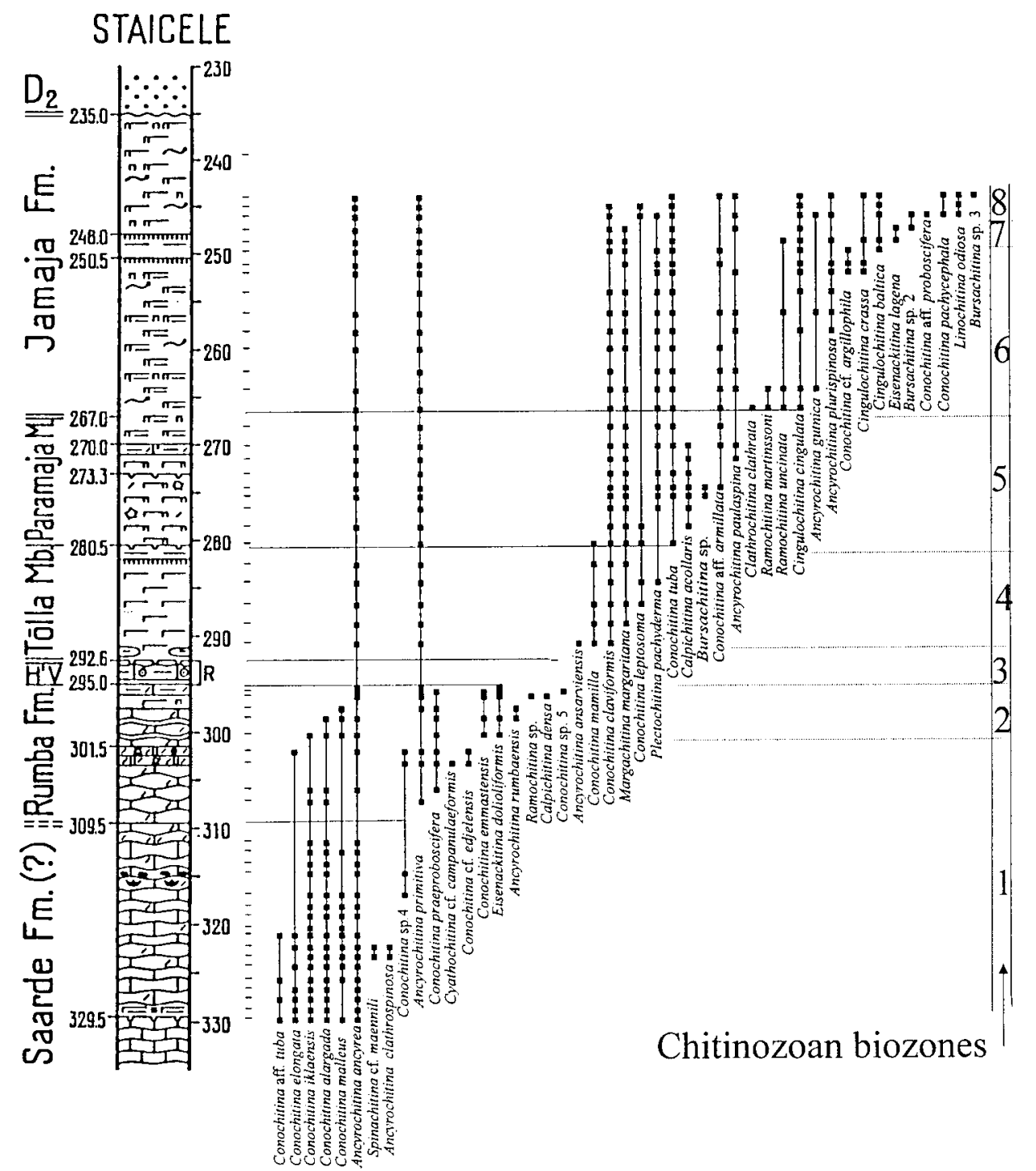

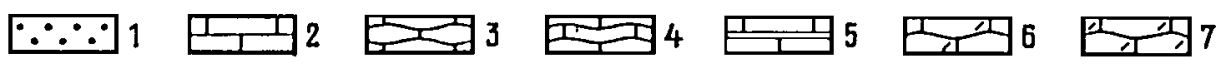

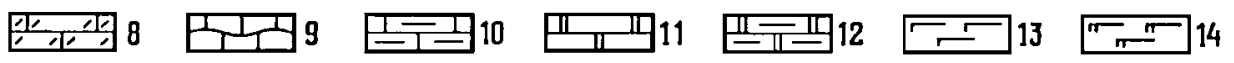

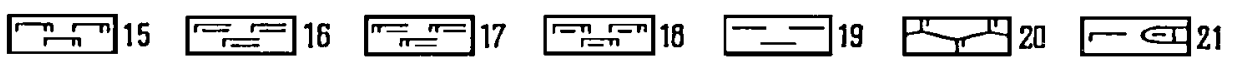

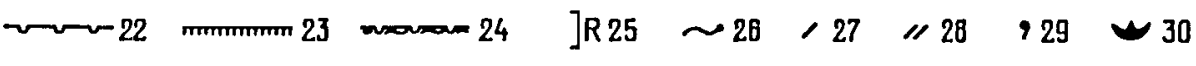

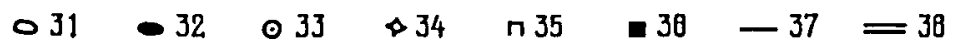


with lithoclasts, and layered stromatolites indicate that the sequence is probably incomplete. The reddish colour of the rocks suggests that only the lower part of the Velise Formation is preserved in the Ikla and Staicele cores, because in several adjacent, stratigraphically more complete cores (Kihnu, Varbla, Seliste, etc.) only the lowermost part of the Velise Formation is red.

\section{Jaani Stage}

The Jaani Stage is represented in the considered sections by the stratigraphical units characteristic of the South Estonian-North Latvian Confacies Belt. The lower part of the stage contains calcareous (in Staicele) to argillaceous (in Ikla) dolomitic marlstones conventionally attributed to the Tõlla Member of the Riga Formation (Aaloe 1970). However, intercalations of dark grey calcareous mudstone with graptolites are lacking in these marlstones and therefore the sections have an intermediate position between the Riga and Jaani formations.

The upper part of the Jaani Stage is represented by marlstones of the Paramaja Member of the Jaani Formation. In the Staicele core the rock is more calcareous and contains much bioclastic material, but the Ikla core shows the prevalence of argillaceous marlstone containing nodules and interbeds of argillaceous limestone. The limestone interbeds are most common in the middle part (interval 256.2-262.4 m) of the Paramaja Member, which obviously corresponds to the Ninase Member developed in more northern sections. In the Ikla core, the Paramaja Member contains the stromatoporoids Densastroma pexisum $(245.3 \mathrm{~m})$, Clathrodictyon linnarssoni $(246.5$ and $261.5 \mathrm{~m})$, and Eostromatopora impexa $(246.5 \mathrm{~m})$, indicating the shallowing-up trend of development.

Fig. 2. Lithological log and range chart of chitinozoan species of the Staicele drill core. Depths from the top of the drill hole are shown in metres. Lithological legend: 1, sandstone; 2, horizontalbedded limestone; 3, nodular limestone; 4, wavy-bedded limestone; 5, limestone-marlstone intercalation; 6 , wackestone; 7 , packstone; 8 , grainstone; 9 , micritic limestone; 10 , argillaceous limestone; 11 , dolostone; 12 , argillaceous dolostone; 13 , marlstone; 14 , highly dolomitic marlstone; 15 , dolomitic marlstone; 16, argillaceous marlstone; 17, dolomitic argillaceous marlstone; 18, calcareous mudstone; 19, mudstone; 20, nodular dolomitic limestone; 21, marlstone with limestone nodules; 22, discontinuity surface (hardground); 23, metabentonite layer; 24, stromatolite with discontinuity surface; 25 , red interval; 26, pyritized burrows; 27, fine bioclasts; 28, coarse bioclasts; 29, pyritized bioclasts; 30, pentamerid brachiopods; 31 , pebbles; 32, pyritized pebbles; 33, oolites; 34, solution vugs; 35 , pyrite mottles; 36 , pyrite; 37 , junction of formations; 38 , junction of stages.

Chitinozoan biozones: 1, Conochitina alargada; 2, Eisenackitina dolioliformis; 3, Interzone III; 4, Conochitina mamilla; 5, Conochitina tuba; 6, Cingulochitina cingulata; 7, Eisenackitina lagena; 8, Conochitina pachycephala. For regional stages see Fig. 4. 


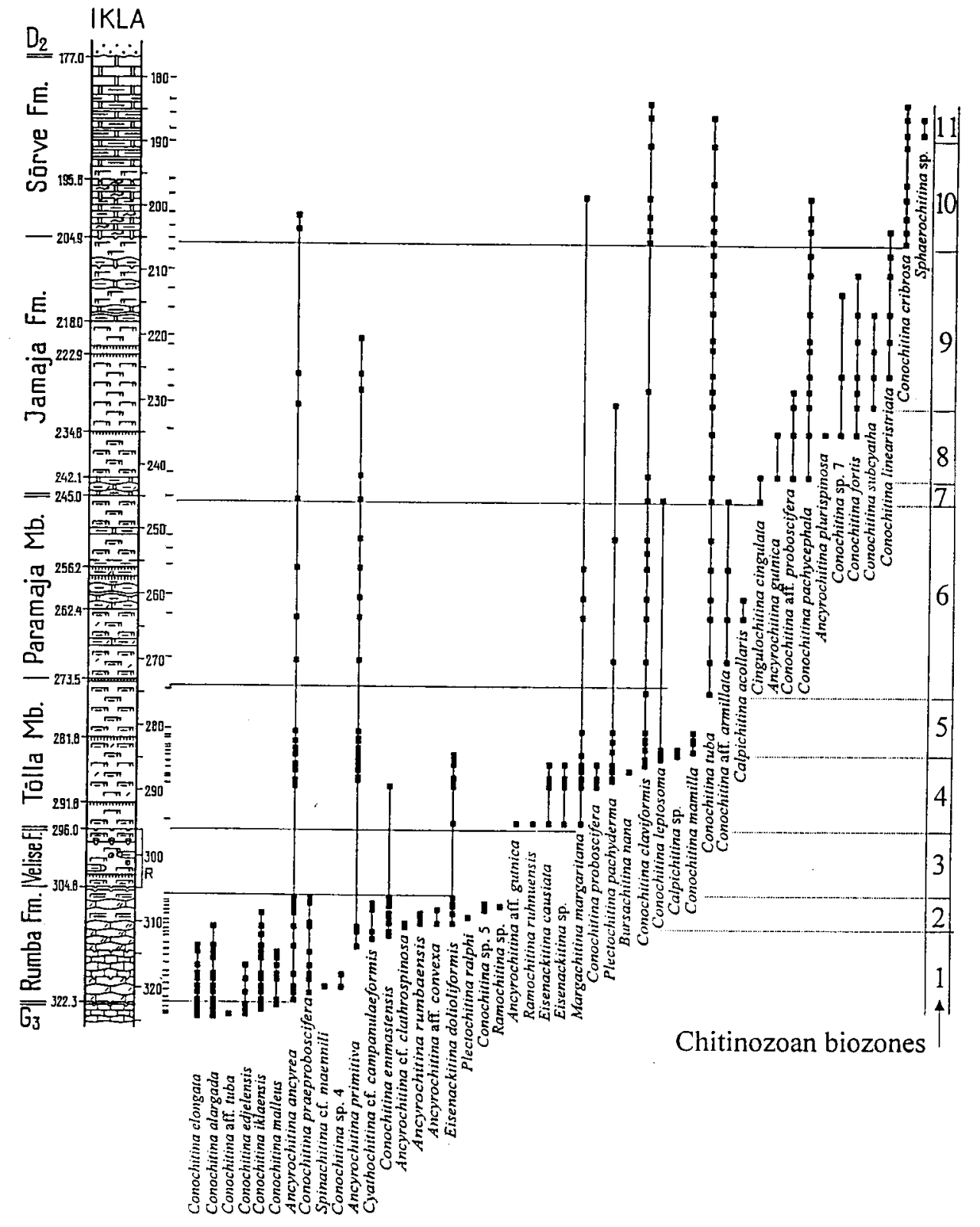

Fig. 3. Lithological log and range chart of chitinozoan species of the Ikla drill core. For lithological legend see Fig. 2. Chitinozoan biozones: 1, Conochitina alargada; 2, Eisenackitina dolioliformis; 3, Interzone III; 4, Interzone IV; 5, Conochitina mamilla; 6, Conochitina tuba; 7, Cingulochitina cingulata or Eisenackitina lagena; 8, Conochitina pachycephala; 9, Conochitina subcyatha; 10, Conochitina cribrosa; 11, ?Sphaerochitina indecora. For regional stages see Fig. 4. 


\section{Jaagarahu Stage}

The Jaagarahu Stage is represented by the Jamaja Formation (below) and the Sõrve Formation (above). The rocks of the Sõrve Formation are preserved only in the Ikla core, but were eroded away completely in the vicinity of Staicele, in lateor post-Silurian time. The Jamaja Formation consists of variably dolomitized marlstones with a carbonate content increasing gradually upwards in the sequence. The marlstone is argillaceous in the lower part of the formation and calcareous in the upper part. It contains pyritized burrows and spots of dispersed pyrite, especially in the Staicele core. In the Ikla core, the uppermost part of the Jamaja Formation (interval 204.9-218.0 m) is characterized by cyclically alternating layers of calcareous marlstone and nodular argillaceous limestone, thus resembling the Riksu Formation developed to the northwest (H. Nestor et al. 2001). In the Ikla drill core a layer of nodular, dolomitized, argillaceous limestone occurs also at the base of the Jamaja Formation (interval 242.1-245.0 m). It contains skeletons of stromatoporoids which point to shallower-water conditions before or after a local hiatus, embracing a great part of the lowermost two Jaagarahu chitinozoan biozones in the Ikla core.

The uppermost portion of the incomplete Silurian sequence in the Ikla core $(177.0-204.9 \mathrm{~m})$ is represented by monotonous platy argillaceous dolomites. The dolomites are heavily bioturbated in their lower part (195.8-204.9 m), but very pure and thick-bedded in the uppermost part $(177.0-181.0 \mathrm{~m})$. In its stratigraphical position this dolomite unit corresponds to the Sórve Formation but in terms of lithofacies it is quite different. The typical Sõrve Formation consists of nodular biomicritic limestones of the open shelf facies zone (according to H. Nestor \& Einasto 1977). The platy dolomites in the Ikla core, however, are probably of restricted shelf genesis, resembling the Muhu Formation but lying much higher in the succession, at the level of a subregional hiatus established in most of the West Estonian sections (V. Nestor \& H. Nestor 1991). Due to lithofacies differences these dolomite strata can be included in the Sorrve Formation only provisionally until their lateral extent is better studied.

The upper Silurian is missing in the considered sections. The rocks of the Jaagarahu Stage are unconformably overlain by the Lower Devonian Kemeri Stage (Väärsi et al. 1969).

\section{SUCCESSION OF CHITINOZOANS}

\section{Adavere Stage}

The chitinozoan range chart of the Rumba Formation in the Ikla core section has been published by V. Nestor (1994, fig. 13/3). It is used in the present paper alongside the new material and partly figured in Pls. I and II.

The lower part of the Rumba Formation of both studied cores is characterized by typical long-ranging middle Llandovery species Conochitina edjelensis 
Taugourdeau, C. elongata Taugourdeau, C. alargada Cramer, C. malleus Van Grootel (nomen nudum), and C. iklaensis Nestor. The species Conochitina praeproboscifera Nestor, Conochitina sp. 4 (in V. Nestor 1994), and Ancyrochitina primitiva Eisenack appear in the lower-middle part of the Rumba Formation in Ikla (313-320 m) (Fig. 3) and in the middle-upper part of the same formation in Staicele (303-316 m) (Fig. 2). This assemblage is characteristic of the Conochitina alargada global Biozone (Verniers et al. 1995), which is usually correlated with the late Aeronian.

\section{Explanation of Plate I}

Fig. 1. Conochitina alargada Cramer 1967, 350-1, Staicele core, depth 321 m, Saarde Formation, Adavere Stage, $\times 140$.

Fig. 2. Conochitina iklaensis Nestor 1980, 350-2, Ikla core, depth 320 m, Rumba Formation, Adavere Stage, $\times 115$.

Fig. 3. Conochitina malleus (nomen nudum) Van Grootel 1990, 350-3, Staicele core, depth 320 m, Saarde Formation, ?Raikküla Stage, $\times 225$.

Fig. 4. Cyathochitina cf. campanulaeformis (Eisenack 1931), 350-4, Ikla core, depth 310.6 m, Rumba Formation, Adavere Stage, $\times 170$.

Fig. 5. Conochitina praeproboscifera Nestor 1994, 350-5, Staicele core, depth 298.2 m, Rumba Formation, Adavere Stage, $\times 220$.

Fig. 6. Ancyrochitina rumbaensis Nestor 1994, 350-6, Ikla core, depth 307.8 m, Rumba Formation, Adavere Stage, $\times 155$.

Fig. 7. Ramochitina sp., 350-7, Staicele core, depth 296 m, Rumba Formation, Adavere Stage, $\times 195$.

Fig. 8. ?Eisenackitina dolioliformis Umnova 1976, 350-8, Staicele core, depth 295 m, Rumba Formation, Adavere Stage, $\times 125$.

Fig. 9. Eisenackitina causiata Verniers 1999, 350-9, Ikla core, depth 294 m, Tõlla Member, Jaani Stage, $\times 400$.

Fig. 10. Eisenackitina sp., 350-10, Ikla core, depth 294 m, Tõlla Member, Jaani Stage, $\times 255$.

Fig. 11. Margachitina margaritana (Eisenack 1937), 350-11, Staicele core, depth 288.5 m, Tõlla Member, Jaani Stage, $\times 310$.

Fig. 12. Conochitina proboscifera Eisenack 1937, 350-12, Ikla core, depth 287.5 m, Tõlla Member, Jaani Stage, $\times 70$.

Fig. 13. Plectochitina pachyderma (Laufeld 1974), 350-13, Staicele core, depth 256.4 m, Jamaja Formation, Jaagarahu Stage, $\times 280$.

Fig. 14. Conochitina claviformis Eisenack 1931, 350-14, Staicele core, depth 288.5 m, Tõlla Member, Jaani Stage, $\times 75$.

Fig. 15. Conochitina mamilla Laufeld 1974, 350-15, Staicele core, depth 288.5 m, Tõlla Member, Jaani Stage, $\times 60$.

Fig. 16. Conochitina leptosoma Laufeld 1974, 350-16, Staicele core, depth 280.3 m, Paramaja Member, Jaani Stage, $\times 75$. 
PLATE I
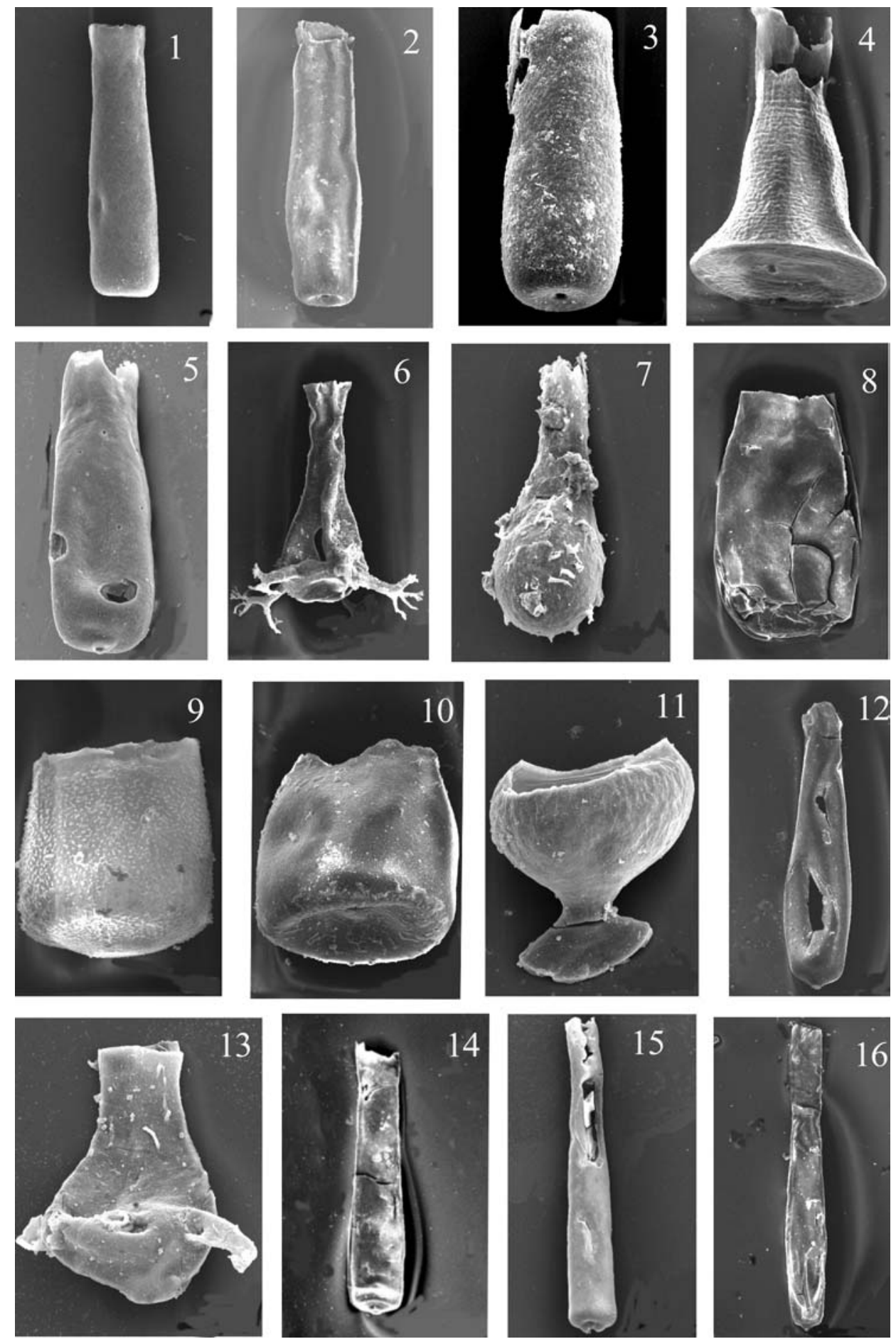
PLATE II
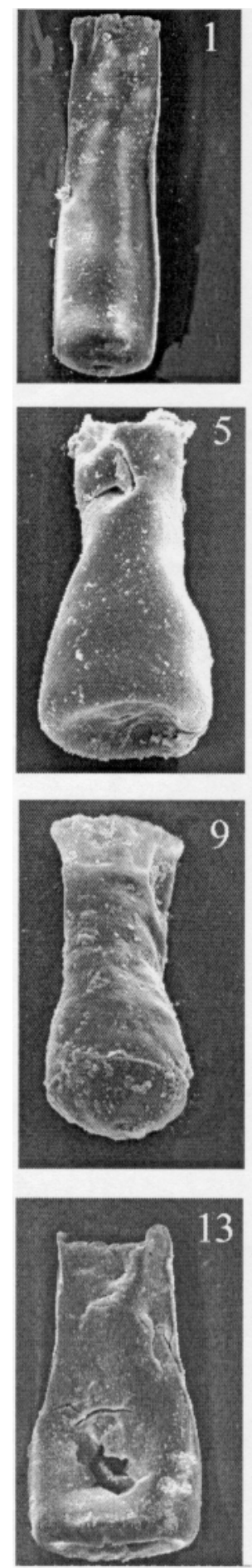
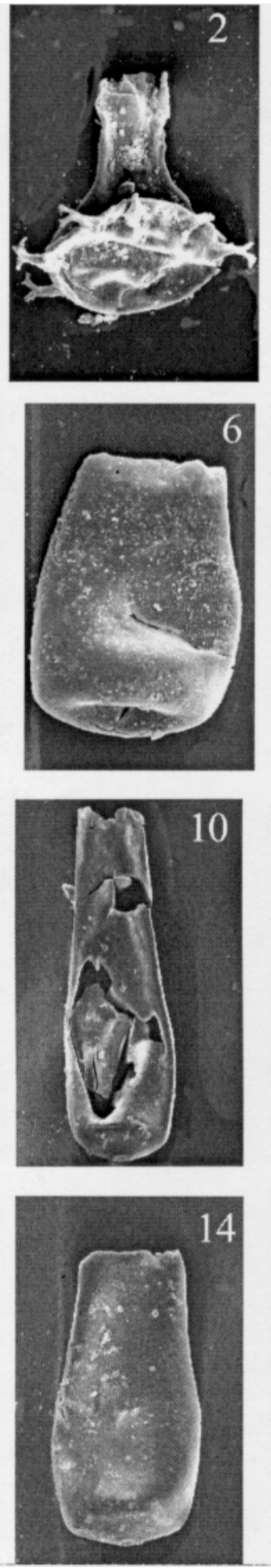
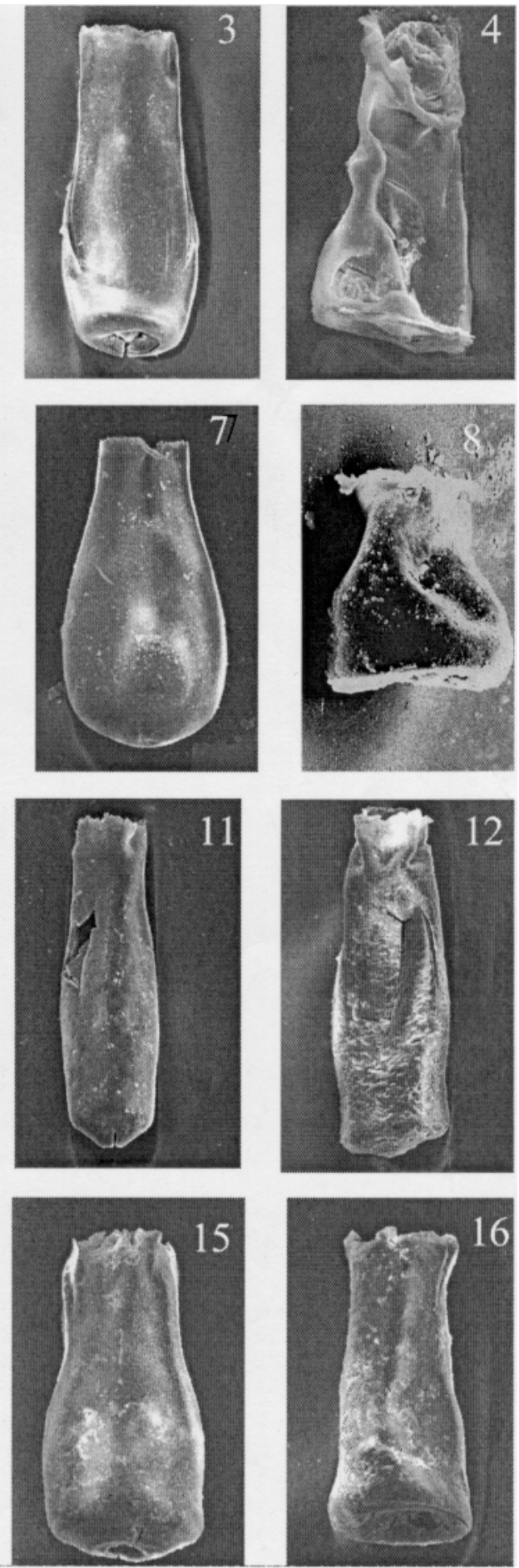
The zonal species of the next global biozone, Eisenackitina dolioliformis Umnova and Conochitina emmastensis Nestor, occur only in the upper part of the Rumba Formation, appearing first in the Ikla core at 309.3 and $311.2 \mathrm{~m}$ and in the Staicele core at 298.2 and $300 \mathrm{~m}$, respectively. Also, short-ranging taxa such as Ancyrochitina rumbaensis Nestor and Conochitina sp. 5 (in V. Nestor 1994) are found in both cores and Ancyrochitina aff. convexa Nestor and Plectochitina ralphi Nestor in the upper portion of the Rumba Formation in Ikla. All longranging chitinozoan species, except Ancyrochitina ancyrea and A. primitiva, occurring in abundance throughout the Aeronian, disappear finally in the upper part of the Rumba Formation.

\section{Explanation of Plate II}

Fig. 1. Conochitina tuba Eisenack 1932, 350-17, Staicele core, depth 274.5 m, Paramaja Member, Jaani Stage, $\times 125$.

Fig. 2. Ancyrochitina paulaspina Nestor 1974, 350-18, Staicele core, depth 270 m, Paramaja Member, Jaani Stage, $\times 265$.

Fig. 3. Conochitina aff. armillata Taugourdeau \& Jekhowski 1963, 350-19, Staicele core, depth $274.5 \mathrm{~m}$, Paramaja Member, Jaani Stage, $\times 130$.

Fig. 4. Cingulochitina cingulata (Eisenack 1937), 350-20, Staicele core, depth 266.2 m, Jamaja Formation, Jaagarahu Stage, $\times 300$.

Fig. 5. Conochitina cf. argillophila Laufeld 1974, 350-21, Staicele core, depth 253.3 m, Jamaja Formation, Jaagarahu Stage, $\times 155$.

Fig. 6. Bursachitina sp. 2, 350-22, Staicele core, depth 247.8 m, Jamaja Formation, Jaagarahu Stage, $\times 320$.

Fig. 7. Eisenackitina lagena (Eisenack 1968), 350-23, Staicele core, depth 249 m, Jamaja Formation, Jaagarahu Stage, $\times 125$.

Fig. 8. Cingulochitina crassa Nestor 1994, 350-24, Staicele core, depth 252.3 m, Jamaja Formation, Jaagarahu Stage, $\times 400$.

Fig. 9. Cingulochitina baltica Nestor 1994, 350-25, Staicele core, depth 246.4 m, Jamaja Formation, Jaagarahu Stage, $\times 345$.

Fig. 10. Conochitina aff. proboscifera Eisenack 1937, 350-26, Ikla core, depth 234 m, Jamaja Formation, Jaagarahu Stage, $\times 130$.

Figs. 11, 12. Conochitina pachycephala Eisenack 1964, Ikla core, Jamaja Formation, Jaagarahu Stage: 11, 350-27, depth $234 \mathrm{~m}, \times 110 ; 12$, 350-28, depth $229.7 \mathrm{~m}, \times 125$.

Fig. 13. Conochitina subcyatha Nestor 1994, 350-29, Ikla core, depth 225 m, Jamaja Formation, Jaagarahu Stage, $\times 215$.

Fig. 14. Conochitina fortis Nestor 1994, 350-30, Ikla core, depth 229.7 m, Jamaja Formation, Jaagarahu Stage, $\times 165$.

Fig. 15. Conochitina cribrosa Nestor 1994, 350-31, Ikla core, depth 202.6 m, Sõrve Formation, Jaagarahu Stage, $\times 175$.

Fig. 16. Conochitina linearistriata Nestor 1994, 350-32, Ikla core, depth 209.5 m, Jamaja Formation, Jaagarahu Stage, $\times 180$. 
The highly reduced Velise Formation is represented by red beds, barren of chitinozoans. This lowermost part of the formation is distinguished as Interzone III (see V. Nestor 1994). The upper part of the formation corresponding to the Angochitina longicollis and Conochitina proboscifera local biozones is obviously lacking in both, cores due to a stratigraphical gap (see below).

\section{Jaani Stage}

In the considered sections, the Riga Formation of the Jaani Stage is represented by the Tõlla Member. Margachitina margaritana (Eisenack), Ramochitina ruhnuensis (Nestor), Eisenackitina causiata Verniers (= Eisenackitina sp. 1 in V. Nestor 1994) (from 294 m), and Conochitina proboscifera Eisenack (from $288.3 \mathrm{~m}$ ) are present in the lowermost Tõlla beds of the Ikla core. However, Angochitina longicollis Eisenack was not found, which may indicate a stratigraphical gap in the Ikla core corresponding to the Margachitina margaritana local Biozone (V. Nestor 1994, p. 129). The occurrence of C. proboscifera and the absence of A. longicollis point to the presence of Interzone IV (V. Nestor 1994, p. 132) in the lowermost part of the Tõlla Member in the Ikla core. In the Staicele core, E. causiata and C. proboscifera are lacking and the Jaani succession begins with Conochitina claviformis Eisenack and Conochitina mamilla Laufeld (from $290.5 \mathrm{~m}$ ) defining the base of the C. mamilla Biozone. The latter biozone is characteristic of the upper part of the Tõlla Member (V. Nestor 1994, p. 132). In the Ikla core, C. mamilla appears at $285 \mathrm{~m}$. Eisenackitina dolioliformis, E. causiata, and Conochitina proboscifera disappear from the sequence at approximately the same level. Thus in the Staicele core the gap at the base of the Jaani Stage (and Wenlock) is bigger than in Ikla and embraces the Margachitina margaritana local Biozone and the succeeding Interzone IV (Fig. 4).

The Jaani Formation is represented by the Paramaja Member in both cores. Near the base of the member appear Conochitina tuba Eisenack (at $274 \mathrm{~m}$ in Ikla, at $280.3 \mathrm{~m}$ in Staicele) and Calpichitina acollaris (Eisenack) (at $262.5 \mathrm{~m}$ in Ikla, at $278.5 \mathrm{~m}$ in Staicele). The former species defines the Conochitina tuba Biozone (V. Nestor 1994, p. 134). The chitinozoan association of the Paramaja Member is dominated by Conochitina claviformis and Margachitina margaritana. The species Plectochitina pachyderma (Laufeld), Conochitina aff. armillata Taugourdeau, and Ancyrochitina paulaspina Nestor are less common. The last species occurs only in the Staicele core.

\section{Jaagarahu Stage}

The chitinozoan assemblage changes distinctly at the lower boundary of the Jamaja Formation in both cores. In the Staicele core, Clathrochitina clathrata Eisenack, Ramochitina martinssoni (Laufeld), and Cingulochitina cingulata (Eisenack) appear at a depth of $266.2 \mathrm{~m}$. These species usually appear in the 


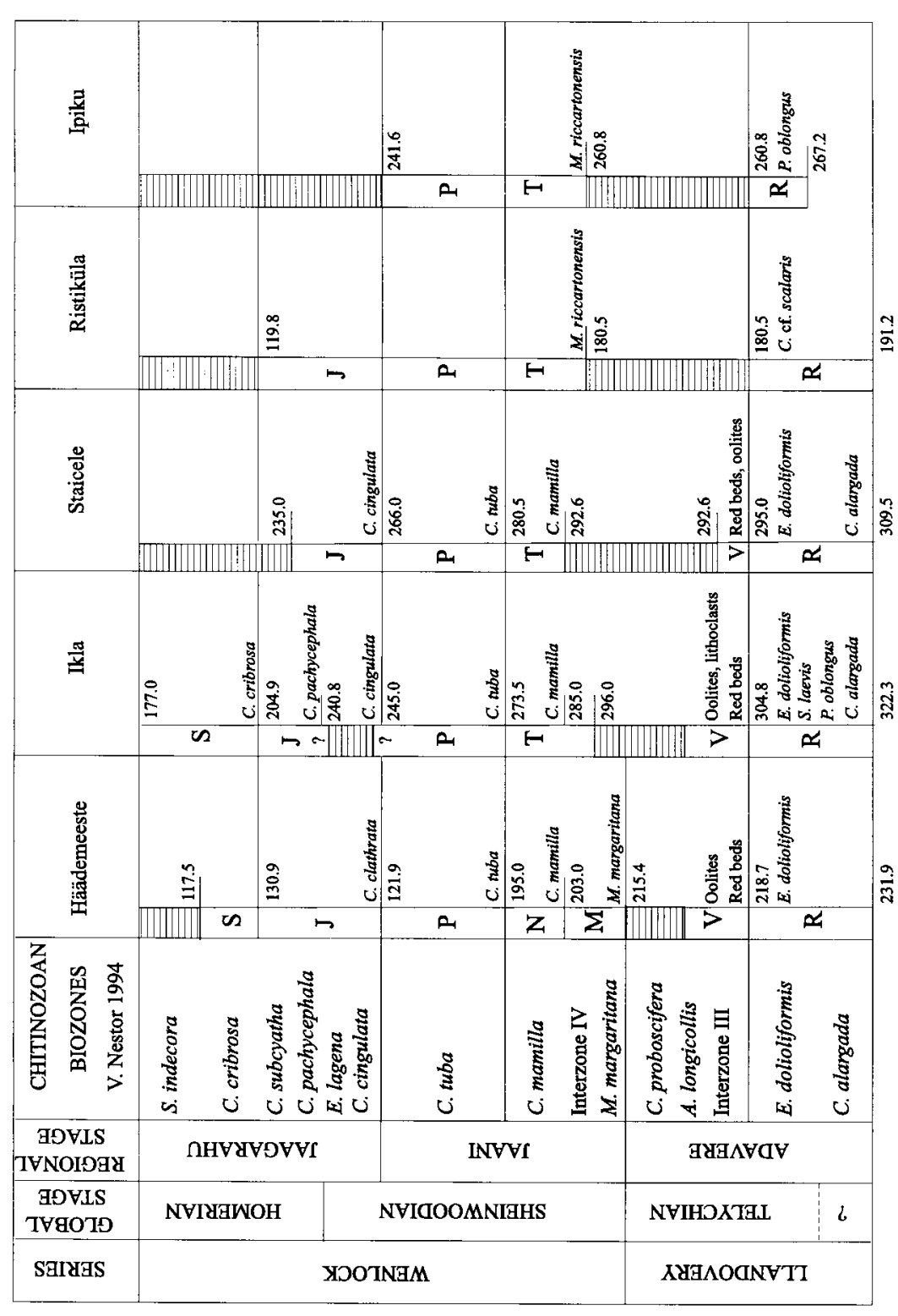

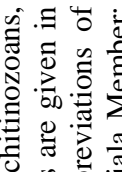

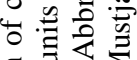

할.

可

矛过

桃

녕

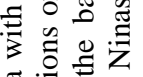

글

ज.

형

एक

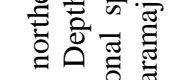

可

.

ప

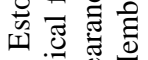

흥 客

큽 읍

늘

论

है

응 흐

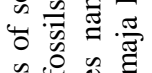

象就

政

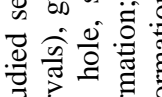

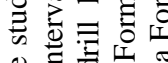

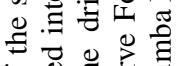

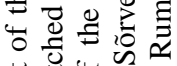

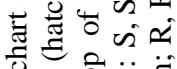

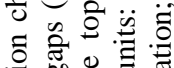

吉哭自

氖氙预

记

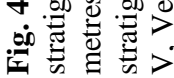


lowermost part of the Jamaja Formation corresponding to the Cingulochitina cingulata Biozone (V. Nestor 1994, p. 134). In the middle part of the Jamaja Formation, Ancyrochitina plurispinosa Nestor, Conochitina cf. argillophila Laufeld, Cingulochitina crassa Nestor, Cingulochitina baltica Nestor, and a zonal species Eisenackitina lagena (Eisenack) appear, the last one at a depth of 249 m, which marks the base of the E. lagena Biozone.

Conochitina pachycephala Eisenack as an index species and Conochitina aff. proboscifera Eisenack determine the next, Conochitina pachycephala Biozone (V. Nestor 1994, p. 136), occurring in the Staicele core in the uppermost part of the local Silurian sequence $(244.5-246.5 \mathrm{~m})$. This shows that temporal counterparts of the uppermost Jamaja (Conochitina subcyatha Biozone) and Sõrve formations are lacking in this core due to late or post-Silurian denudation.

In the Ikla core, an assemblage containing the zonal species Conochitina pachycephala and $C$. aff. proboscifera appears about $4 \mathrm{~m}$ above the base of the Jamaja Formation (at $240.8 \mathrm{~m}$ ). Cingulochitina cingulata, which commonly ranges in the Cingulochitina cingulata and Eisenackitina lagena biozones, is present in this basal interval. This shows that the lower part of the Jamaja Formation, corresponding to the Cingulochitina cingulata and Eisenackitina lagena biozones, has a much reduced thickness in the Ikla core and may contain a local hiatus. However, no clear evidence was found to decide to which part of the C. cingulata and/or E. lagena biozones the supposed hiatus near the base of the Jamaja Formation exactly corresponds (Fig. 4). The upper part of the Jamaja Formation in the Ikla core (interval 206.5-234 m) contains the chitinozoan assemblage of the Conochitina subcyatha Biozone including Conochitina fortis Nestor, C. subcyatha Nestor, C. linearistriata Nestor, and Conochitina sp. 7 (V. Nestor 1994). This biozone is lacking in the less complete Staicele core (Fig. 4).

The typical assemblage of the Sõrve Formation has previously been established only in the Ohesaare and Ruhnu cores (V. Nestor 1994). In the Ikla core, the number of species is more restricted, but Conochitina cribrosa Nestor (from $204.5 \mathrm{~m}$ ) and Sphaerochitina sp. (from $187.8 \mathrm{~m}$ ) enable correlation of the lower part of the formation with the Conochitina cribrosa Biozone and the upper part very tentatively with the Sphaerochitina indecora Biozone.

In conclusion, most of the upper Aeronian to lower Homerian global chitinozoan biozones (Verniers et al. 1995), except the Angochitina longicollis Biozone, are represented in the Ikla and Staicele cores. The Aeronian Conochitina alargada global Biozone (= Conochitina cf. protracta Biozone and Interzone II in V. Nestor 1994) is probably represented by its uppermost part, and the Eisenackitina dolioliformis global Biozone by its lowermost part (= local Conochitina emmastensis Biozone in V. Nestor 1994). The red beds of the Telychian Velise Formation are barren of chitinozoans (local Interzone III). Therefore, the Angochitina longicollis global Biozone is lacking in both cores, as is the local Conochitina proboscifera Biozone (Fig. 4). In the East Baltic sections, the lower Sheinwoodian Margachitina margaritana global Biozone contains four 
local biozones (V. Nestor 1994), from which Interzone IV, Conochitina mamilla, and $C$. tuba biozones are established in the Ikla and the last two also in the Staicele core. The lowermost, local Margachitina margaritana Biozone is not recognized in either the Ikla or the Staicele core. The upper Sheinwoodian Cingulochitina cingulata global Biozone, consisting of the local Cingulochitina cingulata and Eisenackitina lagena biozones, is fully present in Staicele but is represented only in a single sample in the Ikla core (Figs. 3 and 4). The lower Homerian Conochitina pachycephala global Biozone includes the Conochitina subcyatha and C. cribrosa local biozones, all of which are represented in the Ikla core. In the Staicele core only the Conochitina pachycephala local Biozone is recognized. A hiatus corresponds to the C. subcyatha and C. cribrosa local biozones in this core (Fig. 4). The topmost Wenlock global Sphaerochitina lycoperdoides Biozone in the East Baltic area may correspond to the Sphaerochitina indecora local Biozone (V. Nestor 1994, p. 140), but the badly preserved Sphaerochitina specimens in the uppermost part of the Ikla core did not enable precise identification of this zone.

\section{STRATIGRAPHICAL GAPS}

The study of the chitinozoan successions in the Ikla and Staicele drill cores revealed some extensive stratigraphical gaps (Fig. 4). The most prominent hiatus, between the Raikküla and Adavere regional stages, was recognized by V. Nestor (1976) when it became evident that in western Estonia the Pentamerus oblongus Beds or the Rumba Formation unconformably overlapped different subunits of the Raikküla Stage. In core sections on northwestern Saaremaa (Muratsi, Undva, Viki, and Eikla) the Rumba Formation lies on the Järva-Jaani Beds of the Nurmekund Formation which forms the lowermost part of the Raikküla Stage corresponding to the Rhuddanian (H. Nestor 1997, figs. 64 and 65). In a southeasterly direction the stratigraphical range of the hiatus decreases gradually. Thus the gap is almost unrecognizable in the Ikla and Staicele cores, where the nodular wackestones of the Rumba Formation lie upon the cryptocrystalline (micritic) limestones of the Staicele Member of the uppermost Saarde Formation. However, in the Staicele core the thickness of the both units is almost twice as great as in the Ikla core. This leads to a supposition that a stratigraphical gap may exist in the vicinity of Ikla, too, corresponding to the uppermost part of the Staicele Member and/or to the lowermost beds of the Rumba Formation in the Staicele core. There is no chitinozoan biostratigraphical evidence for this, however.

At present no direct evidence is available for exact timing of the late Raikküla sedimentation break in the most complete sections of southwestern mainland Estonia. Records of graptolites from the Staicele Member of the uppermost Saarde Formation are extremely rare. Kaljo (in Kaljo \& Vingisaar 1969) recorded Petalograptus minor Elles and Monograptus gemmatus (Barrande) from the base of the Staicele Member in the Ikla core. Ulst (1973) has identified Demi- 
rastrites ex gr. triangulatus, Coronograptus gregarius (Lapworth), Orthograptus insectiformis (Nicholson), and Rastrites aff. longispinus Perner from the lower part of the Staicele Member in the Staicele core, whereas the upper $45 \mathrm{~m}$ of the member contain only a few biserials. The absence of diagnostic species of the Demirastrites convolutus Biozone and presence of Coronograptus gregarius and Demirastrites ex gr. triangulatus suggest a pre-convolutus Zone age for the lowermost portion of the Staicele Member. Rubel (1977) has identified Stricklandia lens progressa Williams from the Staicele Member in the Ikla core (at $355.9 \mathrm{~m}$ ). This subspecies occurs in the Llandovery type area of southern Wales in the upper Aeronian (Cocks 1989).

Only a few biserial graptolites have been recorded from the overlying Rumba Formation (Kaljo \& Vingisaar 1969; H. Nestor 1972). The formation was provisionally correlated with the Stimulograptus sedgwickii graptolite Biozone (H. Nestor 1972) as it conformably underlies the Velise Formation containing Spirograptus turriculatus Biozone graptolites in the Ohesaare drill core. Recently, however, Loydell et al. (1998) established that only the upper part of the Spirograptus turriculatus Biozone (the Torquigraptus proteus Subzone) is represented in the Ohesaare core. Therefore it is possible that most of the Rumba Formation may actually correspond to the Spirograptus guerichi Biozone and to the lower part of the Spirograptus turriculatus Biozone. From the Rumba Formation of the Ikla core, in the interval of 309.3-321.1 m, Rubel (1977) has identified Stricklandia lens ultima (= Stricklandia laevis Sowerby), which in the Llandovery type area is diagnostic to the lowermost part of the Telychian Stage (Cocks 1989).

The above-stated observations, and first of all the distribution of the species of Stricklandia, allow us to conclude that the junction of the Saarde and Rumba formations, treated also as the boundary between the Raikküla and Adavere regional stages, lies close to the Aeronian-Telychian boundary in their type area in southern Wales. However, the junction of the Conochitina alargada and Eisenackitina dolioliformis global chitinozoan biozones, commonly treated as the Aeronian-Telychian boundary, lies higher in the Ikla and Staicele cores, within the Rumba Formation. This leaves the exact position of the Aeronian-Telychian boundary open. Loydell (1998) stated that a major eustatic fall in sea level occurred near the end of the Aeronian (during the Stimulograptus sedgwickii Chron). The hiatus below the Rumba Formation is presumably connected with this eustatic sea-level low-stand reflecting a glaciation in South America late in the Aeronian (Caputo 1998).

The present study of the chitinozoan successions in the Ikla and Staicele drill cores has revealed a stratigraphical gap near the junction of the Adavere and Jaani stages corresponding roughly to the Llandovery-Wenlock boundary (e.g. Kaljo 1962). In both cores, red to varicoloured marl- and mudstones, barren of fossils, of the Velise Formation (Adavere Stage) are overlain by grey dolomitic marlstones of the Tõlla Member of the Riga Formation (Jaani Stage). In the Staicele core, Conochitina mamilla and C. claviformis, indicative of the Conochitina 
mamilla Biozone, occur at the base of the Tõlla Member (Fig. 4). Thus, the lowermost Wenlock Margachitina margaritana local Biozone and succeeding Interzone IV (V. Nestor 1994) are lacking in the Staicele core (Fig. 4). In the Ikla core, $C$. claviformis and $C$. mamilla appear about 10-12 $\mathrm{m}$ above the base of the Tõlla Member but Angochitina longicollis, which commonly ranges into the Margachitina margaritana Biozone from the upper Llandovery, was not found. Therefore the Margachitina margaritana local Biozone appears to be lacking in this core, and the Jaani Stage appears to begin at the level of Interzone IV (Fig. 4).

The underlying Velise Formation has a reduced thickness in both the Ikla and Staicele cores and shows some shallow-water lithological features (iron oolites, hardgrounds with pyritized pebbles, stromatolites). In some more complete, westerly drill cores of the Velise Formation (Kihnu, Seliste, Eikla, and Viki) red or varicoloured rocks occur only in the basal part of the Velise Formation. This leads to the conclusion that only the lower portion of the Velise Formation is preserved in the Ikla and Staicele cores, while the upper part was not deposited or was eroded away during the end-Telychian to earliest Wenlock break in sedimentation.

Comparison of the Ikla and Staicele cores shows that the gap between the Adavere and Jaani Stages increases towards the east (Fig. 4). In the Ristiküla and Ipiku drill cores (Fig. 1), studied during the geological mapping of the territory (Väärsi et al. 1969), the Velise Formation is totally lacking, and marlstones of the Tõlla Member, with the zonal graptolite Monograptus riccartonensis, directly overlie the nodular wackestones of the Rumba Formation (Fig. 4). Thus, in these sections the hiatus embraces the interval from the Spirograptus turriculatus to the Monograptus firmus graptolite biozones.

The stratigraphical range of the hiatus decreases to the west and northwest. In the Häädemeeste core the Velise Formation has still a reduced thickness and is represented by red beds. The Jaani Stage begins with the Margachitina margaritana local chitinozoan Biozone defined by the co-occurrence of M. margaritana and Angochitina longicollis (V. Nestor 1994, fig. 12/3). Westwards and northwestwards the thickness of the Velise Formation increases markedly and no direct evidence of the hiatus has been found. However, the topmost Llandovery Cyrtograptus insectus graptolite Biozone has not been established anywhere in the East Baltic area, not even in the most complete graptolitic sections of the Baltic Syneclise (Paškevičius 1998). The basal Wenlock Cyrtograptus centrifugus Biozone has been recognized only in the Kurtuvenai-161 borehole in western Lithuania (Paškevičius 1998), where it overlies the Cyrtograptus lapworthi Biozone. In the Ohesaare core in southwestern Saaremaa, graptolitic mudstones of early Cyrtograptus lapworthi Biozone age are overlain by $7.7 \mathrm{~m}$ thick nongraptolitic greenish-grey mudstones, succeeded by dark mudstones with a Cyrtograptus murchisoni Biozone fauna (Loydell et al. 1998). These data show a general sea-level low-stand close to the Llandovery-Wenlock boundary which 
in places may have resulted in a break in sedimentation. In several drill cores (Kihnu, Varbla, Lihula, and Suuremõisa) E. Kala and H. Perens (pers. comm.) discovered scattered lime oolites in the basal layer of the Jaani Formation. These were probably brought in from adjacent shallow-water shoal areas at the beginning of the early Wenlock transgression that reached its maximum in the East Baltic region by the Monograptus riccartonensis Chron (Bassett et al. 1989, p. 161; Paškevičius 1998, p. 122). At that time sedimentation recommenced in the vicinity of Ipiku and Ristiküla, and somewhat later, during the Conochitina mamilla Chron, in Staicele (Fig. 4).

To a certain extent, the hiatus in southwestern mainland Estonia and northernmost Latvia coincides with the Ireviken conodont extinction event (Jeppsson \& Männik 1993; Jeppsson et al. 1995) and also with a prominent positive carbon isotope excursion in the lowermost Wenlock of the Ohesaare, Ruhnu, Ventspils, and Priekule drill cores (Kaljo et al. 1997, 1998; Kaljo \& Martma 2000). The data above support the opinion of Loydell (1998) of a major sea-level drop just prior to the Llandovery-Wenlock transition, which was probably related to a glaciation episode in the Amazon Basin of Brazil at the end of the accumulation of the Nhamundá Formation (Caputo 1998).

One more stratigraphical gap was established in the Ikla core, at the base of the Jamaja Formation, where a great part of the lower Jaagarahu Cingulochitina cingulata and Eisenackitina lagena local chitinozoan biozones is lacking (Fig. 4). The hiatus has not been detected in the adjacent Staicele and Häädemeeste drill cores and has probably only local significance. In southwestern mainland Estonia and northernmost Latvia, the Silurian sequence ends at different levels in the upper Wenlock, which is unconformably overlain by the Lower Devonian Kemeri Stage.

\section{CONCLUSIONS}

Three stratigraphical gaps were established at the boundaries of regional stages in the lower Silurian sections of southwestern mainland Estonia and northernmost Latvia. The hiatuses at the junctions of the Raikküla-Adavere and Adavere-Jaani stages have a considerable areal extent and stratigraphical range, particularly the former. They are probably connected with the global glacio-eustatic sea-level falls near the end of the Aeronian and Telychian (Loydell 1998) corresponding to glacial episodes in the Amazon Basin of Brazil (Caputo 1998). The third gap, near the base of the Jaagarahu Stage (Jamaja Formation), has been recognized only in the Ikla core and has local significance.

The Rumba Formation of the Adavere Stage, hitherto indirectly correlated with the Stimulograptus sedgwickii graptolite Zone and assigned to the Aeronian, belongs, at least partly, to the Telychian based on the presence of the brachiopod Stricklandia laevis in the Ikla core, and Eisenackitina dolioliformis Zone chitinozoans in the upper part of the formation. 


\section{ACKNOWLEDGEMENTS}

This study was supported by the Estonian Science Foundation (grants Nos. 3749 and 5088). We are grateful to R. Einasto for permission to use the unpublished log of the Ikla core and K. Ronk for preparing some illustrations. D. K. Loydell and M. Rubel are thanked for constructive reviews of the manuscript.

\section{REFERENCES}

Aaloe, A. 1970. Jaani Stage. Jaagarahu Stage. In Silur Estonii (Kaljo, D., ed.), pp. 243-264. Valgus, Tallinn (in Russian).

Bassett, M. G., Kaljo, D. \& Teller, L. 1989. The Baltic region. In A Global Standard for the Silurian System (Holland, C. H. \& Bassett, M. G., eds.). Nat. Mus. Wales Geol. Ser., 9, 158-170.

Caputo, M. V. 1998. Ordovician-Silurian glaciations and global sea-level changes. In Silurian Cycles. Linkages of Dynamic Stratigraphy with Atmospheric, Oceanic, and Tectonic Changes (Landing, E. \& Johnson, M. E., eds.). New York State Mus. Bull., 491, 15-25.

Cocks, L. R. M. 1989. The Llandovery Series in the Llandovery area. In A Global Standard for the Silurian System (Holland, C. H. \& Bassett, M. G., eds.). Nat. Mus. Wales Geol. Ser., 9, 36-50.

Einasto, R. 1984. Main stages of development and facies models of the East Baltic Silurian pericontinental basin. In Theory and Practice of Ecostratigraphy (Kaljo, D. \& Klaamann, E., eds.), pp. 37-54. Valgus, Tallinn (in Russian).

Einasto, R., Nestor, H., Kala, E. \& Kajak, K. 1972. Correlation of the Upper Llandoverian sections in West Estonia. ENSV TA Toim. Keemia Geol., 21, 333-343 (in Russian).

Gailite, L. K., Ulst, R. J. \& Jakovleva, V. I. 1987. Stratotipicheskie i tipovye razrezy Latvii. Zinatne, Riga (in Russian).

Jeppsson, L. \& Männik, P. 1993. High resolution correlations between Gotland and Estonia near the base of the Wenlock. Terra Nova, 5, 348-358.

Jeppsson, L., Aldridge, R. J. \& Dorning, K. J. 1995. Wenlock (Silurian) oceanic episodes and events. J. Geol. Soc. London, 152, 487-498.

Kaljo, D. 1962. On the boundary of the Llandoverian and Wenlockian in the East Baltic. ENSV TA Geol. Inst. Uurimused, 10, 97-113 (in Russian).

Kaljo, D. \& Martma, T. 2000. Carbon isotopic composition of Llandovery rocks (East Baltic Silurian) with environmental interpretation. Proc. Estonian Acad. Sci. Geol., 49, 267-283.

Kaljo, D. \& Vingisaar, P. 1969. On the sequence of the Raikküla Stage in southernmost Estonia. ENSV TA Toim. Keemia Geol., 18, 270-277 (in Russian).

Kaljo, D., Kiipli, T. \& Martma, T. 1997. Carbon isotope event markers through the WenlockPřidoli sequence at Ohesaare (Estonia) and Priekule (Latvia). Palaeogeogr. Palaeoclimatol. Palaeoecol., 132, 211-223.

Kaljo, D., Kiipli, T. \& Martma, T. 1998. Correlation of carbon isotope events and environmental cyclicity in the East Baltic Silurian. In Silurian Cycles. Linkages of Dynamic Stratigraphy with Atmospheric, Oceanic, and Tectonic Changes (Landing, E. \& Johnson, M. E., eds.). New York State Mus. Bull., 491, 297-312.

Loydell, D. K. 1998. Early Silurian sea-level changes. Geol. Mag., 135, 447-471.

Loydell, D. K., Kaljo, D. \& Männik, P. 1998. Integrated biostratigraphy of the lower Silurian of the Ohesaare core, Saaremaa, Estonia. Geol. Mag., 135, 769-783.

Nestor, H. 1972. On the stratigraphic range of the beds with Pentamerus oblongus and on the nature of the late Llandoverian transgression in North Europe. ENSV TA Toim. Keemia Geol., 21, 344-350 (in Russian). 
Nestor, H. 1997. Silurian. In Geology and Mineral Resources of Estonia (Raukas, A. \& Teedumäe, A., eds.), pp. 89-106. Estonian Acad. Publ., Tallinn.

Nestor, H. \& Einasto, R. 1977. Facies-sedimentary model of the Silurian Paleobaltic pericontinental basin. In Facies and Fauna of the Baltic Silurian (Kaljo, D., ed.), pp. 89-121. Acad. Sci. Estonian SSR, Tallinn (in Russian).

Nestor, H. \& Einasto, R. 1982. Application of shelf and slope concepts to the Silurian Baltic basin. In Ecostratigraphy of the East Baltic Silurian (Kaljo, D. \& Klaamann, E., eds.), pp. 17-24. Acad. Sci. Estonian SSR, Tallinn.

Nestor, H., Einasto, R., Nestor, V., Märss, T. \& Viira, V. 2001. Description of the type section, cyclicity, and correlation of the Riksu Formation (Wenlock, Estonia). Proc. Estonian Acad. Sci. Geol., 50, 149-173.

Nestor, V. 1976. A microplankton correlation of boring sections of the Raikkuila Stage, Estonia. ENSV TA Toim. Keemia Geol., 25, 319-324 (in Russian).

Nestor, V. 1994. Early Silurian chitinozoans of Estonia and North Latvia. Academia, 4. Estonian Acad. Publ., Tallinn.

Nestor, V. \& Nestor, H. 1991. Dating of the Wenlock carbonate sequences in Estonia and stratigraphic breaks. Proc. Estonian Acad. Sci. Geol., 40, 50-60.

Paškevičius, J. 1998. The Geology of the Baltic Republics. Vilnius Univ., Geol. Surv. Lithuania, Vilnius.

Rubel, M. 1977. Evolution of the genus Stricklandia (Pentamerida, brach.) in the Llandovery of Estonia. In Facies and Fauna of the Baltic Silurian (Kaljo, D., ed.), pp. 193-212. Acad. Sci. Estonian SSR, Tallinn (in Russian).

Ulst, R. 1973. Llandoverian deposits of northern Latvia and their correlation. In Problemy regional'noj geologii Pribaltiki i Belorussii (Kuršs, V. M., ed.), pp. 71-85. Zinatne, Riga.

Väärsi, A. R., Kajak, K. F., Kajak, H. V., Kirs, E. E. \& Liivrand, H. J. 1969. Report of the SouthEstonian Geological Squad on complex geological-hydrogeological mapping on the scale $1: 200000$ of the southwestern part of Estonia (card O-35-XIII) for 1966-1968. Geol. Surv. Estonian SSR, Keila (unpublished report in Russian).

Verniers, J., Nestor, V., Paris, F., Dufka, P., Sutherland, S. \& van Grootel, G. 1995. A global Chitinozoa biozonation for the Silurian. Geol. Mag., 132, 651-666.

\section{Ülem-Llandovery-Kesk-Wenlocki (Silur) litostratigraafia ja kitinosoade biostratigraafia Edela-Eestis ja Põhja-Lätis}

\section{Heldur Nestor ja Viiu Nestor}

On esitatud andmed Adavere, Jaani ja Jaagarahu lademe litostratigraafilise liigestuse ning kitinosoade leviku kohta Ikla ja Staicele puursüdamikus. Adavere lademe Rumba kihistu on vähemalt osaliselt Telychi vanusega. Redutseerunud paksusega Velise kihistu punavärvilised merglid esindavad vaid kihistu alumist osa. Settelüngad Raikküla-Adavere ja Adavere-Jaani lademe vahel on märkimisväärse pindalalise leviku ja stratigraafilise ulatusega ning peegeldavad tõenäoliselt glatsio-eustaatilisi merepinna langusi, mis vastavad mandrijäätumistele Lõuna-Ameerikas Aeroni ja Telychi lõpul. Jaagarahu lademe alumisele osale vastav lünk Ikla puuraugus on seevastu lokaalse tähendusega. 


\title{
Литостратиграфия и распространение хитинозой в верхнем лландовери-среднем венлоке (силур) Юго-Западной Эстонии и Северной Латвии
}

\begin{abstract}
Хелдур Нестор и Вийу Нестор
Приведены данные о литостратиграфическом расчленении и распространении хитинозой в адавереском, яаниском и яагарахуском горизонтах в скважинах Икла и Стайцеле. Румбаская свита адавереского горизонта относится, во всяком случае частично, к подъярусу Телич. Маломощные красноцветные мергели велизеской свиты представлены лишь в нижней части свиты. Стратиграфические перерывы между райккюласким и адавереским, а также между адавереским и яаниским горизонтами имеют широкое площадное распространение и заметный стратиграфический диапазон. Они, вероятно, отражают гляцио-эвстатические понижения уровня мирового океана, связанные с оледенениями в Южной Америке. Стратиграфический перерыв в основании яагарахуского горизонта в скважине Икла имеет локальное значение.
\end{abstract}

